\title{
AMERICAN POLITICAL DISCOURSE: OUTSIDER PERCEPTIONS AND ATTITUDES
}

\author{
Boryana Kostova ${ }^{1}$
}

\begin{abstract}
American political discourse understood as political speeches delivered by American presidents reaches not only American citizens but the international community, i.e. numerous audiences from various cultures due to media coverage. The paper attempts to reveal the attitudes towards American values by studying the perceptions of American political discourse and the ability to recognize the persuasive and legitimation strategies. Drawing on the contemporary theoretical assumptions of political discourse, a small-scale survey was conducted among university students. The results of the survey will be used as a point of departure for the development of new specialized languages courses.
\end{abstract}

Key words: political discourse, political speeches, perceptions, attitudes

\section{Introduction}

"In the USA today the poles are so upside down, people have become so unnormal [...]. It is due to political correctness and gender culture that all values are being destroyed." (Dachkov, 2019) This opinion given by an outsider to American culture, a Bulgarian who participated in an Oscar-Winning movie, criticizes the trend towards anti-intellectualism in the American society. Indeed, it is not infrequent that popular culture and the media represent contemporary American life in such a way that creates negative impressions of it. Thus, it has become hard to recognize the West or the western values that were idealized in the past. However, there is another 'window' into the culture and the values of a nation. The text and talk associated with American institutions, especially when implemented by powerful political actors, can bring insights into the beliefs, assumptions, attitudes and images that shape American identity. As Austermühl (2014, pp. 8-9) points out, "beyond their political value, American presidential discourse primarily represents a cultural phenomenon. [...] Political discourse in general and presidential discourse in particular play significant roles in shaping American culture and American national identity."

Political speeches delivered by American presidents aim to reach not only American citizens but the international community as well. As these speeches are covered and commented on by the media on a daily basis and are available as

1. Senior Lecturer at Varna Free University, Department of Foreign Language Teaching, Varna, Bulgaria, e-mail: boryana.kostova@abv.bg. 
text and video online, they can reach numerous audiences from various cultures. Drawing on these assumptions, the paper attempts to reveal the attitudes of Bulgarian students about American values by studying their perceptions of American political discourse. One of the issues which arises is whether viewers from an outsider culture can recognize the persuasive and legitimation strategies as such or take them either for granted or as a fact. In order to investigate how these features and trends are perceived, a small-scale study was conducted. The study does not claim to be representative but rather to throw light on the current views of a small group of young people from Europe.

\section{Previous research in the field}

Defining the term "political discourse" is not a straightforward matter because it is a multifaceted and even fuzzy concept. It may refer to a type of discourse which is political production - both text and talk, or "conventional ways of talking that create and perpetuate systems of ideology, sets of beliefs about how the world works and what is natural" (Johnstone, 2008, p. 29). In our daily lives we are confronted with many genres of this type of political discourse: political speeches, debates, political interviews, policy documents, etc. These are official genres, designed for the public and demonstrating the many ways in which politicians like to present themselves and their work, and how they like to be perceived by their various audiences. On the other hand, the term could refer to any text or talk that is either about a political subject or which is politically motivated (Wilson, 2015b, p. 775). Any piece of extended talk or text produced by or for political actors can be considered political discourse as well as family talk about political events since the topic of talk is about political events or issues (Chilton, 2004, pp. 124-134; Wodak, 2012). Some linguists even argue that all language is inherently political, therefore almost all language use could be seen as "political discourse" (Joseph, 2006).

To overcome the burden of the complexities around the term "political discourse", its meaning will be restricted to cover a contextualized language use by particular language users in particular political settings. So, I will be using the term "American political discourse" to refer to political speeches delivered by American presidents at different formal occasions. According to some researchers (Austermühl, 2014; Chilton, 2017; Kranert, 2018; Lakoff, 1996; Reyes, 2014) contemporary American political discourse is characterized by a number of salient features among which are the use of political myths, appeal to emotions by discursive construction of a sense of threat, metaphorical reasoning, and the interplay between formal and informal register.

One of the typical features of contemporary American political discourse is the employment of political myths. Political myths are understood as "narratives accepted as valid in its essentials by the group and can be 
understood as ideologically marked narratives which are associated with the values, assumptions and goals of a specific ideology or identifiable family of ideologies" (Kranert, 2018, p. 887). Myths tell stories about what exists and why, and these stories are presented as divinely revealed or inspired by inevitable, superhuman causes. They are deeply embedded in human thinking, because in their cognitive development people are exposed to many different culturally specific narratives on which behavior is based. The function of political myths is to facilitate an emotional connection with the audience. This can be achieved because myths manage to link the political reality with the private experience of the participants and make the social differences irrelevant. Therefore, they are a preferred rhetorical tool used by politicians (ibid., pp. 888-889).

According to Austermühl's analysis and overview of literature (2014, pp. 116121) political myths or civil religious themes in American presidential discourse have a prominent position. Four main themes or topoi can be distinguished:

- Destiny under God refers to the notion of Americans' exceptional status as a chosen people. The settlement of America is considered as the opening of a grand scheme and design in Providence for the illumination of the ignorant and the emancipation of the slavish part of mankind all over the world.

- Exodus is associated with the idea of an American Israel and the narrative of the nation's exodus. The Revolution is seen as the final act of the Exodus from the old lands across the waters. The Declaration of Independence and the Constitution were sacred scriptures and Washington the divinely appointed Moses who led his people out of the lands of tyranny. In this view Europe is Egypt; America, the promised land. God has led his people to establish a new sort of social order that shall shed light into all nations.

- Sacrifice is the theme of death, sacrifice and rebirth, the new birth of freedom after the Civil War.

- International example stresses America's position as an international role model, as the antiwar movement and the black movement of the 1960s were hoped to result in a viable and coherent world order.

There are four additional themes which are recurrent in contemporary presidential speeches:

- America's status as a global role model promotes America as the ideal of democracy. America is represented as the first truly democratic country where democracy is based on institutions and the constitution and understood as the government by the people, especially the rule of the majority, government in which the supreme power is vested in the people and exercised by them directly or indirectly through a system of representation with periodically held free elections. 
- The confrontation between good and evil is the depiction of global politics as a Manichean struggle between good and evil. This rhetorically casts the United States and her allies as forces of good and those who oppose them and the values they represent as evil.

- Nation's prosperity construes an image of America as the most prosperous nation.

- Kranert (2018) has observed another recurrent use of political myths, particularly allusions to a past golden age in politics. The term "golden age" is used to describe a period in history remembered for its prosperity and happiness. The Golden Age for the USA is considered the period of economic prosperity between the end of the WWII in 1945 to the early 1970s when the Bretton Woods monetary system collapsed. This period marked the achievement of high and sustainable economic growth, high levels of labour productivity growth together with low unemployment. It is this period that is supposedly needed to come back to in order to overcome current problems. The golden age myth is represented by re-derivations in English such as 're-' meaning again; 're-' meaning 'back again', 'back to the original', 'back to the good old times', part of the nostalgia rhetoric, for example renewal, reconstruct, restore, rebuild (ibid., pp. 891-894). It is most obvious in a slogan such as 'Make America great again' in Donald Trump's campaign.

The references to political myths have three main functions: culture building, culture affirmation, and most importantly legitimation of political actions.

According to Chilton (2017), another typical feature of American political discourse is the activation of exclusionary concepts which trigger fear responses. This is achieved by the verbal representation of threat to self (e.g. Mexican illegal immigrants) and the verbal (self-) representation of individuals as capable of removing external threats (e.g. the President as a hero building a partition wall): the speaker is representing himself in the role of protector of the people, in a context evoking emotions of threat and fear when home territory is threatened by an enemy who is countered by a hero and savior. Chilton (ibid.) even argues that emotional responses can also be triggered through person deixis (personal pronouns $I$, we, they) and the usage and repetition of lexical items. The lexical items have recurrent meanings. The word wall, for example, is linked to cognitions of spatial separation. It is linked to the container schema. The word prison also depends on the container schema. These words stimulate mental representations of the Other. The prison keeps us safe by containing the other; border walls keep us safe from the other's intrusion into our inside space. These basic bodily schemas are in play in word meaning. Due to their repeated use by the speaker in the same speech, they acquire persuasive power. That is 
how emotions or pathos manage to override argumentation and evidence or logos.

American political discourse can be understood within a metaphorical framework. In Lakoff's view (1996), what differentiates Republicans from Democrats, or conservatives from progressives as they are referred to in his works, is not their ideological positions. Rather, they have a distinctive way of thinking and talking about politics that is based on two specific family-based moral systems. Morality, according to Lakoff, is understood to a large extent metaphorically and conceptualized in terms of a limited number of metaphors. What characterizes American political discourse is the link between familybased morality and politics. According to this way of thinking, a nation is conceptualized as a family, the government as a parent and the citizens as the children. Lakoff (ibid.) distinguishes two basic family models: the Strict Father (SF) model, characterizing conservative morality, and the Nurturant parent (NP) model, which is typical of the progressive morality. Both models are idealized cognitive models, similar to frames, which are structures that enable the organization of knowledge.

The SF model revolves round the notion of discipline. The major assumption is that 'people are inherently bad, life is difficult, and the world is fundamentally dangerous' (Lakoff, 1996, pp. 4-19), so there is a need for a strong and strict father to make children good. Lakoff (ibid.) defines cognitive metaphors used by Republicans which reflect conservative moral values and revolve around strength, self-interest and self-reliance. He (ibid.) also provides a list of typical conservative terms and phrases, which include over 30 words among which are the following: character, virtue, discipline, strong, self-reliance, individual responsibility. Lakoff (ibid.) claims that the different SF moral metaphors find expression in actual conservative policies. For example, when the metaphor of moral order is applied to American foreign policy, we can notice how Republicans speak of America as being on top of all other nations as the world's moral authority and the leader to be followed and admired.

The Nurturant parent metaphor, on the other hand, is connected to a family model which gives priority to nurturance over discipline, where nurturance is understood as empathy and responsibility towards other people. The expressions that Lakoff (ibid., pp. 20-31) finds indicative of progressive talk include: social responsibility, free expression, human rights, equal rights, concern, care, help, and health, among others. When NP moral metaphor is applied to politics, progressive American politicians talk about how America should protect its people from external threats by building and maintaining strong diplomatic alliances and pursuing wise foreign and domestic policy, and that America's leading role in the world will be strengthened by helping people around the world to have a better life. In line with this reasoning, America is represented 
by Democrats as having the moral obligation and moral duty to help those who are weaker and less prosperous both internally and externally.

Another typical feature of contemporary American political discourse is the interplay between formality and informality which is used to convey a political message. Reyes (2014) traces it at the level of lexical choices and marked register usages, the textual organization of the speeches in terms of their structure and predictability, intertextuality, and non-verbal communication, especially the relationship of laughter with formality. The function of formality is to establish the ethos of the speaker, to show authority and command of the subject but results in distancing from the public. Informality, on the other hand, is responsible for the pathos of the speech, or the speaker's emotional connection with the audience, by placing the detail of the message at a secondary level. Pathos is extremely important for politicians today because information is shared most effectively at the emotional level. The emotional connection with the audience is reached by "displaying solidarity at different levels, for example by speaking like them, using cultural images shared by a social class, or narrating personal experiences that touch and move the audience, provoking sympathy" (Reyes, 2014, p. 543). Sometimes a speech resembles a pseudo-conversation with the audience, while the speaker resembles an entertainer. This colloquial manner makes a speech less predictable and creates a sense of authenticity (Montgomery, 2017).

\section{Research Questions}

In order to study the perceptions of Bulgarian students of American political discourse a small-scale survey was conducted. It is based on a questionnaire which aims to gather personal, subjective views on how political text and talk is perceived and whether this influences the attitudes towards America. The ten open-end questions have been devised in line with the contemporary assumptions of American political discourse. The following questions have been developed:

- Which political myths associated with American society are dominant today?

- How is America represented in public text and talk?

- In what role are American politicians representing themselves?

- In what role is the American politician representing other countries?

- What kind of emotions are American politicians evoking?

- Do you think it is OK when American politicians use informal language in formal situations?

- Do Bulgarian/native politicians structure their arguments in a similar way? 
- What is your attitude towards such argumentation/ way of speaking by politicians?

- Which values of American society do you favor most/least?

- Would you like to visit, study or work in the USA? Why?

\section{Methods}

The paper focuses on American political discourse as represented in presidential speeches and aims to explore the way it is perceived by representatives of an outside culture. Therefore, the methods of analysis employed are Content and Critical Discourse Analysis. The corpus of answers given to the questions in the questionnaire was analyzed and the examples were extracted manually.

\section{Data Analysis}

A total of 25 Bulgarian and international students have been used as informants. They include 10 second and fourth year students of International Relations, 6 first year students of Psychology, 7 students of English and American Studies ${ }^{2}$, and 2 Erasmus students of Political Sciences from Italy and Poland. Only three of them have visited the USA. Before giving their responses the students were asked to read excerpts from five speeches and to watch the full version of the speeches. The purpose of this preliminary task was to focus the attention of the students but not to limit their answers to cover only the speeches in the list. The speeches, given by three American presidents at different occasions and in front of different audiences, included George Bush's Remarks to Military Personnel and Their Families at Fort Benning, Georgia given on January 11, 2007; Barack Obama's first inaugural address given on January 20, 2009; Donald Trump's Gettysburg speech given during his election campaign on October 22, 2016; Donald Trump's inaugural address given on January 20, 2017; and Donald Trump's Remarks to the United Nations General Assembly in New York City given on September 19, 2017 (Woolley \& Peters, 2010).

\section{Results/ Key findings}

The first question triggered various responses. According to $60 \%$ of the informants Ideal of democracy is a dominant political myth associated with American society today. Some of the responses in this group provide specific reasons on which the ranking is based: [1] "The USA is the first country which introduced the constitution for society. They have the oldest constitution in the

2. Special thanks to Prof. Dr. Rumyana Todorova for conducting the survey among her students at Shumen University, Department of English Studies. 
world and the other countries copied this idea"; [2] "Everyone in the USA is equal before the law despite the fact that the nation is formed from different cultures"; [3] "Americans think they are the best in the political field. They have the awareness that their democracy is an example for the other countries. That is why they are active in many parts of the world to bring democracy. However, democracy is a great regime only for the USA". Other political myths include America as Example for other nations (for 56\% of the informants), Beacon or torch which shows the way (for $40 \%$ of the informants) and America as a Land of opportunities (for $48 \%$ of the informants), American dream (for $40 \%$ of the informants) because [4] "America has unlimited capacity. With hard work and honest work everyone can achieve great success"; [5] "America gives more opportunities than other countries to study and live better". The myths that the informants find less dominant are America as a City upon a hill (for $28 \%$ of the informants) and Promised land (for 20\% of the informants). The myth that is hardly associated with America is the Golden age myth (for only $8 \%$ of the informants).

The findings of the study show that the most recognizable political myth associated with America according to the respondents is the Ideal of democracy. It is more popular than American dream or Land of opportunities. One explanation for this finding can be that the word democracy is recurrently exploited in political text and talk as a central notion in the contemporary world and is charged with a highly positive semantic prosody. It must be noted here that the biggest sub-group of the respondents is formed by the twelve students of International Relations who are conscious of the fact that democracy stands for institutions established by a constitution. The fact that America has the first written constitution that is used as a model is valued highly by the respondents. The least recognizable are the civil religious myths Promised land, City upon a hill and Beacon/torch which shows the way. This may be explained by the lack of familiarity with the cultural history of the USA. Despite the fact that the Golden age myth is well exploited by populist politicians both in America and throughout Europe, only two of the respondents noticed its presence.

The following answers were given to the second question. According to $56 \%$ of the respondents America is represented in public text and talk as a global leader, a model, a prime example of how a country should behave, has the appearance the rest of the world has to accept, flawless, a hero of the world and feels obliged to defend the world, a righteous arbiter. $40 \%$ of the respondents have noticed that America is represented as a great nation, the most prosperous and powerful nation on Earth. 36\% of the respondents have come across representations of America as a country that has lost its way and everyone is getting advantage of that but its strength, wealth and greatness can be recovered. $28 \%$ of the students find America represented both as a country of democracy, based on equality and the rule of people and a friend to other nations because it [6] "seeks friendship 
and goodwill with the nations of the world"; [7] "is capable of working in a team"; [8] "is ready to support and defend other nations and allies"; [9] "is ready to cooperate with other states as long as American people can benefit". America is seen as a land of opportunities, freedom, happiness, equal rights, hope, dreams and aspirations which come true by $20 \%$ of the respondents. Another $12 \%$ of the respondents have noticed that America is shown as a nation based on values, such as family values, and respects the legacy of its values. Only $4 \%$ of the respondents have seen representations of America as a country that will chase its national interest over all.

More than half of the respondents have the impression that America is depicted in political text and talk as a global leader who is flawless to the extent of being a hero. Seeing America as a righteous arbiter and a model positions it as a Strict Father to other nations. About $40 \%$ of the respondents have noticed representations of America as the most prosperous and powerful nation of which the other countries are taking advantage. Less than $30 \%$ of the students have pointed out that America is shown as a friend to other nations, but ready for cooperation only if this is mutually beneficial.

The third question produced the following responses. American politicians represent themselves in the role of a close friend (according to $80 \%$ of the respondents), protector of the people (76\%), savior/ messiah (56\%), servant to the people (for $56 \%$ of the respondents), preacher and hero (for $44 \%$ of the respondents), nurturing parent (40\%), strict father/ leader of the most powerful country who dictates the way to the world (28\%). The students commented that [10] "American politicians represent themselves differently. The role they choose to identify with depends on the situation and the political purpose"; [11] "American politicians would consider to take action in world politics needed or not. They make sure they would work for a better world but they wouldn't forget about America".

The findings have proved that the respondents understand that selfrepresentation depends on the situation, the audience, and the political purpose. They noticed that there are two roles of American politicians that are almost equally dominant despite being at the opposite sides of the spectrum. These are the self-representations as a close friend and protector of the people. Selfrepresentations as savior and messiah, are well recognized as synonymous and are perceived as equally important. Interestingly, self-representations as servant to the people are perceived as frequently employed as that of savior and messiah. Self-representations formulated as Nurturant parent and Strict father are less recognizable as students might not be familiar with the broad range of metaphors used in International Relations.

The respondents gave the following answers to the fourth question. They recognized the role in which the American politicians represent the other 
countries as allies (64\%) and useful friends (48\%) because [12] "American goals are more important than those of the other countries"; [13] "America puts its interest above all"; [14] "If friends do not satisfy requests, they become enemies". $44 \%$ of the students have come across representations of other countries either as dangerous criminals, thieves and murderers, who create chaos and terror and pose threat to the whole world or as enemies (32\%) and villains (24\%). Only $4 \%$ of the respondents have seen the idea of other countries as helpless, incapable of surviving without the support of the USA.

Students commented that American politicians judge the other countries on the basis of their political convictions and actions. They insist that other countries change their policy and believe that those countries which are friends to America must follow America in its fight against the wrong positions. The respondents perceive the Other-representations as positive rather than negative. Students have the impression that other countries are more often represented as allies and friends who are useful for America to reach its goals than enemies and dangerous criminals who pose threat to the whole world. There are two interesting responses which lie somewhere in the middle of the spectrum according to which other countries are perceived as victims - they are either helpless and cannot survive without the help of the USA or will be used in some or other by the USA.

The answers to the fifth question reveal the respondents' perceptions of the emotions politicians evoke in their speeches. These can be divided into positive emotions such as peace and security (for $64 \%$ of the respondents), intimacy (for $32 \%$ ), happiness from being proud (for 32\%), compassion (for 12\%), gratefulness to people who fight for America (for 4\%) and negative emotions which include fear (for 60\%), threat (for 36\%), anger (for $8 \%$ ), contempt (4\%), insecurity (for $4 \%$ ). The students are well aware that politicians use complicated rhetoric and psychological tactics when they want to win the audience. Still they feel that positive emotions of peace and security, intimacy and happiness of being proud outweigh the negative emotions of fear and threat that are evoked in public discourse. What they are concerned about is that [14] "one of the main actors on the world stage can make such controversial speeches. This is worrying".

The sixth question triggered the following responses. Most of the respondents $(84 \%)$ perceive the use of informal language in formal situations as something very natural on condition that the situation allows it. They are aware of two important aspects of informality. First, informality may be an effective icebreaking strategy, appealing to pathos, constructing solidarity, building trust as [15] "The message is conveyed more easily to the audience"; [16] "When politicians sound close and friendly, they can reach the heart of people and win their trust and respect"; [17] "It motivates people think more positively, leading to a better results". Second, politicians can sound authentic rather than 
speakers who have learnt their lines by heart, they [18] "show that they are themselves, reveal themselves to the audience". Only a small number, one fifth of the respondents perceive the use of colloquial language in formal speeches as risky or disrespectful because [19] "formal political speeches should rely predominantly on clear argumentation".

Responding to the seventh question, the students gave examples of how Bulgarian/native politicians structure their arguments similarly to American politicians. According to the respondents this represents strategic use of language as [20] "In order to achieve their goals Bulgarian politicians use tools and strategies similar to the ones used by American politicians". These strategies include delegitimation of the political opponent, negative Other-representation, self-representations as heroes, better than their political opponents, empty and unjustified arguments instead of real ones, use of political myths, especially the myth of the messiah and the myth of the bright future, and use of informal language.

The respondents' attitude towards the argumentation/ way of speaking by politicians has been expressed as a response to the eighth question. More than half of the respondents $(61 \%)$ feel that the argumentation used currently by political leaders both native and foreign can be misleading even to people who study Political Sciences and who are familiar with political matters because [21] "The same political clichés are used by different politicians"; [22] "Politicians always come with loud promises, hopes and wishes for change"; [23] "Politicians tend to exaggerate during election campaigns". Only $38 \%$ perceive this type of argumentation in a positive rather than negative light as [24] "Combining formal and informal style can win more respect when a politician presents him/ herself as a harsh leader with a soft side".

The ninth question asked about the values of American society which students favor most or least. Despite the way in which American politicians talk about America and other countries and the respondents' perceptions of American political discourse, about two thirds of the respondents (72\%) have a positive attitude towards America and Americans. The values of American society that are appreciated can form three broad groups. The first group of values focus on the rules that exist at every level of society, both institutional and interpersonal. This group includes such values as democracy, the constitution, the rule of law, fair play: [25] "There are rules for everybody and people respect each other"; [26] "American society is based on equality and individual freedom to express your opinion therefore Americans always have opinion about everything". The second group of values towards which the respondents have a positive attitude concern the Americans: their work life, their attitude towards themselves and their country: [27] "American people are hardworking and achievement oriented"; [28] "Americans are filled with self-confidence and self- 
determination, have motivation for development and progress"; [29] "American people are polite, kind, supportive, always want to help you and appreciate what you do". The third group of values refers to American leaders and American standard of living: [30] "American leaders" first interest is America and they will do everything to recover the country, will not work with other countries unless they give something in return"; [31] "President Obama and his rhetoric"; [32] "How President Bush switches from formal to informal style". Only less than one third of the respondents (27\%) express criticism. The critical attitude is directed not towards American values, but rather towards American political text and talk and American foreign policy: [33] "I agree with American values and in part with American positions. It's true that America is a powerful and prosperous nation. But now America and all the western civilization discuss the issues of democracy, human rights and freedoms only as a way to achieve their goals"; [34] "America is often represented as a leader to other countries. However, America has its defects, for instance, racism. Therefore I can't understand how this country can be the right example for others. In America people can buy guns freely. How can American politicians promise their people to make America safe again when even citizens with mental problems can own a gun and use it. I don't agree that all countries should repeat such actions"; [35] "I don't like it when the USA defines itself as the best nation on earth. Patriotism is very important but it mustn't become drastic. I don't like the overpatriotic and patronizing tone used in political text and talk".

The tenth question asked the students for the reasons behind their motivation to gain insight and embodied experience of the USA. Two thirds of the respondents would like to visit, study or work in the USA. This reflects their positive attitude to the country which is viewed as amazing as [36] "It's a beautiful country with stunning sights, skyscrapers and cities"; [37] "It's different from Europe and gives you a different point of view", to the Americans who are different but in a positive way because [38] "American people are polite, kind, supportive and appreciate the work you do", to intercultural encounters which are part of International Relations studies and [39] "it is a unique experience to get to know American culture better". Some of the students wish to continue their studies in the USA because of the prestige they can achieve as [40] "Every employer will hire a person with a diploma from the USA". However, most of them would like to participate in short-term work and travel programs because [41] "There are a lot of jobs and lower taxes".

One of the students is more ambitious wishing to work for an international organization based in the USA. Only one third of the respondents have a critical attitude. They are either not interested in visiting the USA or think that unlike Europe, American society has many problems and they wouldn't fit in there because [42] "It is not a country where I could build a family"; [43] "The tuition fees are very expensive unless you get a scholarship"; [44] "I've never been 
attracted to the lifestyle of the USA. American society is too complicated, there are many problems and there's too much difference between the wealthy and the poor. This is probably due to the big competition that exists in all aspects of society". There is only one respondent who expresses a straightforward negative attitude towards America: [45] "Visiting America had been a dream of mine while I was growing up. I had pictured it as a paradise land, land of opportunities and riches. Recently I have changed my mind. In my opinion, you can make your dreams come true wherever you are as long as you're working hard and never give up. Now I prefer living in Europe. Europe is my safe place even if the recent events show otherwise. I would like to make my mark in Europe and to be successful in Europe".

\section{Conclusion}

The findings of the survey show that students, those studying International Relations and Psychology in particular, are very realistic about how politicians use language for persuasion. They are able to recognize the strategies of legitimation of certain policies or of a candidate during election campaigns employment of political myths, self- and Other-representations and informality. They noticed that there is a similarity between how American and Bulgarian politicians use these strategies although in their view Bulgarian politicians are much more modest in this respect. Unlike some researchers of political discourse (Chilton, 2017; Wodak, 2017), who are concerned about the scarcity of real arguments, populist appeals to emotions, the activation of exclusionary concepts, the respondents do not find the strategic use of language as a dangerous socio-political behavior. They may not like the over patriotic tone of the political speeches or the return to the idea of self-interest and self-help in contemporary international relations, but they do not find it problematic. Despite how the political text and talk is realized and how the media recontextualizes it, the respondents have preserved their positive attitude towards the core values of the American society, i.e. respect for rules, the individual and hard work. On the other hand, they do not see themselves as part of American society or as potential political or economic emigrants. For the most part, the respondents wish to be visitors and gain intercultural and/or work experience.

\section{Implications}

The findings of the survey have important implications for pedagogical intervention. The respondents of the study are young people who need to develop more insight into political text and talk. The study showed that they have little familiarity with the political myths arising from American civil religion. Also, the respondents do not realize the seriousness of the fact that 
political discourse and American political discourse in particular has more functions than argumentative legitimation or delegitimation. Because of being in the focus of all media, it does not only represent reality, but it construes reality, projects social identities and asserts models of behavior.

The way political myths are used as ideologically marked narratives and how language is used for persuasion and legitimation are not included in the courses of political science or international relations. The place of such topics is within specialized language courses devoted to language, culture and civilization. This can broaden the agenda of university foreign language courses to focus not only on teaching and learning language for international communication in terms of the four communicative skills. The teaching materials should be designed around the rhetorical strategies of public communication and develop knowledge of the broader socio-political context and the specifics of the genres of public communication, an understanding of the audience, practice of the skills for comprehension and production of texts which belong to certain dominant genres. Such an approach can result in deeper understanding of the hidden mechanisms of political discourse and possibly to critical attitude to political text and talk.

\section{References:}

Austermühl, F. (2014). The great American scaffold: Intertextuality and identity in American presidential discourse. Amsterdam/ Philadelphia: John Benjamins.

Charteris-Black, J. (2013). Analysing political speeches: Rhetoric, discourse and metaphor. Basingstoke: Palgrave Macmillan.

Chilton, P. (2004). Analysing political discourse: Theory and practice. London/ New York: Routledge.

Chilton, P. (2017). Toward a neuro-cognitive model of socio-political discourse, \& an application to the populist discourse of Donald Trump. Langage et Societe. DOI: 10.3917/ 1s.160.0237.

Dachkov, J. (2019). Oskarite kato grozen znak na dneshniya svyat. Galeriya, 27 Feb-5 March 2019.

Johnstone, B. (2008). Discourse analysis (2 ${ }^{\text {nd }}$ edn.) Malden, MA: Blackwell.

Joseph, J. (2006). Language and politics. Edinburgh: Edinburgh University Press.

Kranert, M. (2018). Political myth as legitimation strategy. The case of the golden age myth in the discourses of the Third Wave. Journal of Language and Politics, 17(6), 882-906.

Lakoff, G. (1996). Moral politics: How Liberals and Conservatives think. Chicago, IL: University of Chicago Press.

Montgomery, M. (2017). Post-truth politics?: Authenticity, populism and electoral discourses of Donald Trump. In R. Wodak \& M. Krzyżanowski (Eds.) Right Wing Populism in Europe: Contesting Politics \& Discourse Beyond 'Orbanism' and 'Trumpism'. Special issue of Journal of Language and Politics, 16(4), 619-639. 
Reyes, A. (2014). Bush, Obama: (in)formality as persuasion in political discourse. Journal of Language and Politics, 13(3), 538-562.

Van Leeuwen, T. (2007). Legitimation in discourse and communication. Discourse \& Communication, 1(1), 91-112.

Wilson, J. (2015a). Talking with the President: The pragmatics of presidential language. New York: Oxford University Press.

Wilson, J. (2015b). Political discourse. In D. Tannen, H. E. Hamilton, \& D. Schiffrin (Eds.), The handbook of discourse analysis (2 ${ }^{\text {nd }}$ edn.), pp. 775-794. London: Wiley Blackwell.

Wodak, R. (2012). Politics as usual: Investigating political discourse in action. In J. P. Gee \& M. Handford (Eds.), The Routledge handbook of discourse analysis (pp. 525-540). London/ New York: Routledge.

Wodak, R. (2017). The "Establishment", the "Elites", and the "People": Who is who? Right Wing Populism in Europe: Contesting Politics \& Discourse Beyond 'Orbanism' and 'Trumpism'. Special issue of Journal of Language and Politics, 16(4), 551-565.

Woolley, J. T., \& Peters, D. (2010). The American presidency project. Santa Barbara, CA. Retrieved from: www.presidency.ucsb.edu/index.php. 